\title{
Assessment of Irrigation Practices of Farmers Receiving Water from Open-Canal and Piped Irrigation Networks
}

\author{
Nihan Körpe Aslan, Murat Tekiner* \\ Department of Agricultural Structures and Irrigation, Agricultural Faculty, Çanakkale Onsekiz Mart University, 17020 Çanakkale, Turkey
}

\section{ART I C LE IN F O}

\section{Research Articles}

Received 08 March 2017

Accepted 12 July 2017

\section{Keywords:}

\section{Irrigation scheduling}

Water use efficiency indicators

Piped and open-canal irrigation networks

Drip irrigation method

*Corresponding Author:

E-mail: mtekiner@comu.edu.tr

\section{A B S T R A C T}

Open-canal irrigation networks have been transformed into closed-piped networks. Drip irrigation is the most common method used irrigations in Çanakkale province. The aim of study is to assess irrigation practices of farmers using different irrigation networks. There were not significant differences in irrigation practices of the farmers receiving water from both networks, but all were making mistakes and unconscious in their practices. An optimum schedule was also prepared to compare with farmer practices. While a farmer growing tomato in Kumkale village with piped-network was expected to apply $531 \mathrm{~mm}$ irrigation water as seasonal total, present farmer applied $1414 \mathrm{~mm}$ water; while a farmer growing tomato in Mahmudiye village with open-canal network was expected to apply a total of $457 \mathrm{~mm}$, present farmer applied $492 \mathrm{~mm}$ irrigation water; while a farmer growing maize in Kumkale village with piped-network was expected to apply $512 \mathrm{~mm}$, the present farmer applied $975 \mathrm{~mm}$; finally a farmer growing maize in Mahmudiye village with opencanal network was expected to apply $379 \mathrm{~mm}$ water, the present farmer applied $228 \mathrm{~mm}$ irrigation water throughout the entire growing season. Irrigation water efficiency (IWUE) values indicating the effects of irrigation water quantities on yields were calculated as 2.5 $\mathrm{kg} / \mathrm{da} / \mathrm{mm}$ for tomato culture in Kumkale; $12.3 \mathrm{~kg} / \mathrm{da} / \mathrm{mm}$ for tomato culture in Mahmudiye; $0.7 \mathrm{~kg} / \mathrm{da} / \mathrm{mm}$ for maize culture in Kumkale and $8,7 \mathrm{~kg} / \mathrm{da} / \mathrm{mm}$ for maize culture in Mahmudiye village. Relative irrigation supply (RIS) values indicating how efficiently the precipitations were used were calculated as 2.98 for tomato culture in Kumkale; 1.41 for tomato culture in Mahmudiye; 2.40 for maize culture in Kumkale and 0.85 for maize culture in Mahmudiye village.

Türk Tarım - Gıda Bilim ve Teknoloji Dergisi, 5(9): 1066-1070, 2017

\section{Açık Kanal ve Borulu Şebekelerden Sulama Yapan Çiftçilerin Sulama Uygulamalarının Değerlendirilmesi}

\section{A K A L E B İ L G İ S İ}

\section{Araştırma Mmakalesi}

Geliş 08 Mart 2017

Kabul 12 Haziran 2017

\section{Anahtar Kelimeler:}

Sulama zaman planlamas 1

Su kullanım etkinliği göstergeleri

Borulu ve açık kanallı sulama şebekesi

Damla sulama yöntemi

"Sorumlu Yazar:

E-mail: mtekiner@comu.edu.tr

\section{Ö Z E T}

Özellikle açık kanallı küçük sulama şebekelerinin hızla borulu şebekeye dönüştürüldüğü ve damla sulama yönteminin yoğun bir şekilde kullanıldığı Çanakkale yöresinde yapılan bu çalışma ile açık kanal ya da borulu şebekeden su alan çiftçilerin sulama zaman planlaması bakımından farklı olmadığı her iki şebekeyi kullanan çiftçi grubunun da bilinçsiz sulama yaptığı belirlenmiştir. Optimum sulama programına göre Kumkale'de domates yetiştiriciliği yapan çiftçi mevsimlik toplam $531 \mathrm{~mm}$ sulama suyu uygulaması gerekirken borulu şebeke ile $1414 \mathrm{~mm}$, Mahmudiye'deki domates yetiştiricisi $457 \mathrm{~mm}$ sulama suyu uygulaması gerekirken açık kanallı şebeke ile $492 \mathrm{~mm}$, Kumkale' de mısır yetiştiricisi $512 \mathrm{~mm}$ sulama suyu uygulaması gerekirken borulu şebeke ile $975 \mathrm{~mm}$ ve son olarak Mahmudiye'deki misır yetiştiriciliği yapan çiftçi ise $379 \mathrm{~mm}$ sulama suyu uygulaması gerekirken açık kanallı şebeke ile $228 \mathrm{~mm}$ sulama suyu uygulamıştır. Diğer taraftan sulama suyu miktarının verime etkisini gösteren göstergelerden IWUE değerleri sirasiyla Kumkale domateste; $2,5 \mathrm{~kg} / \mathrm{da} / \mathrm{mm}$, Mahmudiye domateste; $12,3 \mathrm{~kg} / \mathrm{da} / \mathrm{mm}$, Kumkale misırda; $0,7 \mathrm{~kg} / \mathrm{da} / \mathrm{mm}$ ve Mahmudiye misirda ise $8,7 \mathrm{~kg} / \mathrm{da} / \mathrm{mm}$ olarak belirlenmiştir. Ayrıca sulama suyu ihtiyacının karşılanma oranının ve yağışın etkili kullanılıp kullanılamadığını gösteren RIS değerlerinde ise durum, Kumkale domateste; 2,98, Mahmudiye domateste; 1,41, Kumkale misirda; 2,40 ve Mahmudiye misirda 0,85 olarak hesaplanmıştır. 


\section{Introduction}

Water is the most essential component of human life. Increasing populations and resultant increases in food demands also increase direct demands for water. Such increasing demands are reducing available water resources per capita. Water-saving technologies should be put into practice to meet such ever-increasing demands. Agriculture is the primary sector in which water-saving technologies are to be applied. Savings in this sector will bring about various positive impacts as compared to the other water-user sectors.

According to a UN report, agricultural productions will increase $67 \%$ in developing countries between the years 2000-2030. It is predicted that such an increase could not be met with currently available water resources. In this case, agricultural sector should then produce more with higher quality but less water (Anonymous, 2006).

Çanakkale province of Turkey has available water resources potential of $2392 \mathrm{hm}^{3}$ and about $90 \%$ of irrigations are performed through pressurized irrigation methods (TÜIK, 2014). Agricultural production lands of Çanakkale province are provided in Table 1.

Already constructed open canal irrigation networks are not being converted into pressurized-piped networks and the ones in design phases are designed as piped networks. With the transition into piped networks, water losses through conveyance are significantly reduced and better water distribution planning is achieved as compared to open-canal networks. Operation and maintenance are also significantly reduced in piped-networks.

In present study, irrigation practices of farmers using piped-irrigation networks and open-canal networks were compared. Irrigations of the farmers in both groups were monitored and optimum irrigation schedules were compared with the schedules implemented by the farmers.

The present study was derived from a Graduate Thesis Research Project supported by The Scientific Research Projects Department of Çanakkale Onsekiz Mart University (Project ID: FYL-2014-330).

\section{Material and Method}

\section{Material}

Four plots were selected as the research area based on irrigation method, irrigation system, dominant annual crops of the region and availability of plots for reliable measurements for the year 2015. The first and the second plots (1 and 2) are located in Kumkale village of Ezine town $27 \mathrm{~km}$ South of Çanakkale province. The third and fourth plots (3 and 4) are located in Mahmudiye village of Ezine town $39 \mathrm{~km}$ South-west of Çanakkale province. All plots presented in Figure 1 are located over Kumkale plain. The information about the experimental plots is provided in Table 2.

Soil analyses were performed to determine soil characteristics of the plots and results are provided in Table 3.

As can be inferred from Table 3, Mahmudiye soils had high field capacity and permanent wilting point values since the plain is an alluvial plain and contain large amount of Basin Clay. These values comply with the physical values of basin clay specified in Rijtema (1970).
On the other hand, Kumkale soils mostly had loamy texture and thus physical values were lower than Mahmudiye soils. Kumkale soils also had higher bulk density values than Mahmudiye soils.

The research province, Çanakkale, is located at Northwestern section of Anatolia and southwest section of Tracie and at the South end of Marmora Sea along both sides of Dardanelles. The province has a transitional climate between Mediterranean and Black Sea climates (Karagöz, 2001). Long-term (1990-2014) meteorological data revealed that research site had an annual average temperature of $14.8^{\circ} \mathrm{C}$ and annual precipitation of 608.9 $\mathrm{mm}$.

\section{Method}

To compare the farmers using different irrigation networks, irrigation dates, durations and amount of irrigation water in each irrigation were recorded in all plots. Also, the yields at the end of season were also determined to compare different networks.

Class-A pan was used for optimum scheduling. The open cylindrical pan was $120.7 \mathrm{~cm}$ in diameter, $25 \mathrm{~cm}$ high and made of galvanized plate (number 22) in accordance with the principles specified in Yildirım and Korukçu (1999). Evaporation readings were performed at 09:00 in the morning in two-day intervals. However, twoday readings were then converted into daily readings while making irrigation schedules. The plots in Kumkale village had piped networks and farmers were able receive water only in Monday, Tuesday and Wednesday according to rotation plan of the irrigation association. Therefore, optimum schedules were prepared based on their water distribution plans.

Table 1 Agricultural production lands of Çanakkale province*

\begin{tabular}{l|c}
\hline Total land resources (ha) & 993.318 \\
\hline Agricultural lands (ha) & 331.633 \\
Irrigable lands (ha) & 113.258 \\
Vegetable production lands (ha) & 20.187 \\
Table tomato production lands (ha) & 5.560 \\
Industrial tomato production lands (ha) & 3.084 \\
Field crops production lands (ha) & 258.251 \\
Kernel maize production lands (ha) & 5.392 \\
Silage maize production lands (ha) & 15.012 \\
\hline
\end{tabular}

*GTHB (2016)

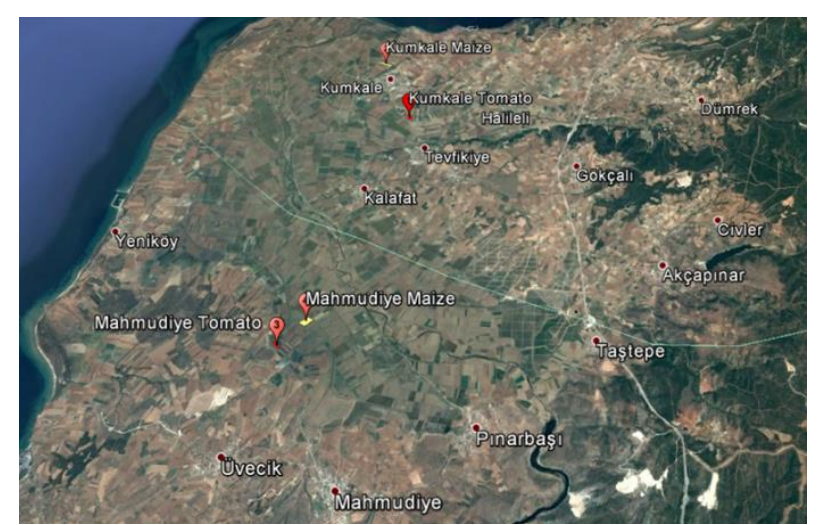

Figure 1 Location of experimental plots 
Table 2 Information about selected plots

\begin{tabular}{|c|c|c|c|c|c|c|c|}
\hline $\begin{array}{l}\text { Plot } \\
\text { No }\end{array}$ & Town & Village & $\begin{array}{l}\text { Water-user } \\
\text { Organization }\end{array}$ & $\begin{array}{l}\text { Irrigation } \\
\text { Network }\end{array}$ & $\begin{array}{l}\text { Irrigation } \\
\text { Method }\end{array}$ & $\begin{array}{l}\text { Plot Size } \\
\text { (da) }\end{array}$ & Plant \\
\hline 1 & Ezine & Kumkale & Truva Irrigation Association & Piped & Drip (trickle) & 12 & Tomato \\
\hline 2 & Ezine & Kumkale & Truva Irrigation Association & Piped & Drip (trickle) & 20 & Maize \\
\hline 3 & Ezine & Mahmudiye & Pınar Irrigation Association & Open-canal & Drip (trickle) & 14 & Tomato \\
\hline 4 & Ezine & Mahmudiye & Pinar Irrigation Association & Open-canal & Drip (trickle) & 38 & Maize \\
\hline
\end{tabular}

Table 3 Soil characteristics of experimental plots for the year 2015

\begin{tabular}{l|cccc}
\hline \multicolumn{1}{c|}{ Plot } & Soil Depth $(\mathrm{cm})$ & Field Capacity $(\%)$ & Permanent Wilting Point $(\%)$ & Bulk Density $\left(\mathrm{g} / \mathrm{cm}^{3}\right)$ \\
\hline \multirow{2}{*}{ Mahmudiye } & $0-30$ & 50.0 & 32.6 & 1.15 \\
Tomato & $30-60$ & 43.2 & 26.8 & 1.26 \\
& $60-90$ & 27.4 & 17.9 & 1.30 \\
\hline \multirow{2}{*}{ Kumkale } & $0-30$ & 37.3 & 24.5 & 1.18 \\
Tomato & $30-60$ & 42.2 & 26.3 & 1.21 \\
& $60-90$ & 42.6 & 26.3 & 1.20 \\
\multirow{2}{*}{ Mahmudiye } & $0-30$ & 42.7 & 28.5 & 1.20 \\
Maize & $30-60$ & 42.9 & 28.3 & 1.13 \\
& $60-90$ & 47.8 & 30.4 & 1.20 \\
\multirow{2}{*}{ Kumkale } & $0-30$ & 35.8 & 23.9 & 1.30 \\
Maize & $30-60$ & 37.7 & 24.9 & 1.26 \\
\end{tabular}

Amount of irrigation water to be applied in optimum irrigation schedule was calculated by using the equation recommended by Kanber et al. (1994) as follows:

$$
\mathrm{I}=\mathrm{Epan} \times \mathrm{kp} \times \mathrm{P}
$$

Where;

I : Amount of irrigation water to be applied ( $\mathrm{mm})$,

Epan :Cumulative evaporation measured from ClassA pan $(\mathrm{mm})$,

kp :Plant-Pan coefficient,

$\mathrm{P} \quad$ :Plant cover percentage (\%).

Local wind speed, average relative humidity and the place of evaporation pan were considered in finding plantpan coefficient $(\mathrm{kp})$ and the tables and figures provided in Doorenbos and Pruitt (1992) were used.

Amount of irrigation to be applied to plots in optimum schedule was calculated by using the equation recommended by Eylen et al. (1986) for pressure-dripper discharge-time relations:

$$
\mathrm{T}=\mathrm{I} \times \mathrm{A} / \mathrm{q} \times \mathrm{n}
$$

\section{Where;}

$\mathrm{T}$ :Irrigation water application duration (hours),

I :Amount of irrigation water to be applied (mm),

A :Plot size $\left(\mathrm{m}^{2}\right)$,

q :Dripper discharge at operational pressure (liter/hour),

$\mathrm{n}$ :Number of drippers in plot.

Irrigation water use efficiency (IWUE) and relative irrigation supply (RIS) criteria were used to assess the irrigation practices of the farmers (Howell et al, 1990):

$$
\mathrm{IWUE}=\mathrm{Ey} / \mathrm{I}
$$

Where;

IWUE :Irrigation water use efficiency $(\mathrm{kg} / \mathrm{da} / \mathrm{mm})$,

Ey :Economic yield $(\mathrm{kg} / \mathrm{da})$,

I :Irrigation water (mm).

$$
\mathrm{RIS}=\mathrm{I} / \mathrm{ET}-\mathrm{Pe}
$$

Where;

RIS : Relative irrigation supply,

I : Irrigation water (mm),

ET : Plant water consumption (mm),

$\mathrm{Pe} \quad$ : Efficient precipitation $(\mathrm{mm})$.

Growth stages and plant coefficients $(\mathrm{Kc})$ used in plant water consumption (ET) calculations were obtained from Plant Water Consumption Manual of Irrigated Plant of Turkey (GTHB, 2016).

Irrigation data for water use efficiency indicators at optimum conditions were obtained from optimum values calculated from evaporation pan and yield values were obtained from optimum values reported in previous studies carried out with the same plant and species in Çanakkale.

\section{Results and Discussion}

Optimum irrigation schedules calculated for present rotation plan of the association in plots 1 and 2 in Kumkale village and the irrigation schedules practiced by the farmers were presented in Figures 2-9. Water use efficiency indicators of the same plots are provided in Tables 4-7.

As can be inferred from Figure 2 presenting irrigation schedule prepared by considering water supply to the network only on Monday, Tuesday and Wednesday, soil moisture level did not drop below the critical level and amount of applied irrigation water did not exceed water holding capacity of the soils.

On the other hand in farmer practices (Figure 3), soil moisture level went below the critical level 4 times and excessive amounts were applied in all irrigations. Since drip irrigation was used in experimental plots, excess water was assumed not to runoff, but deep percolated. 


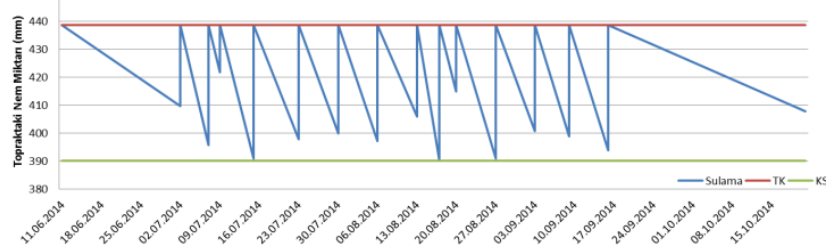

Figure 2 Optimum irrigation scheduling (Kumkale-Tomato)

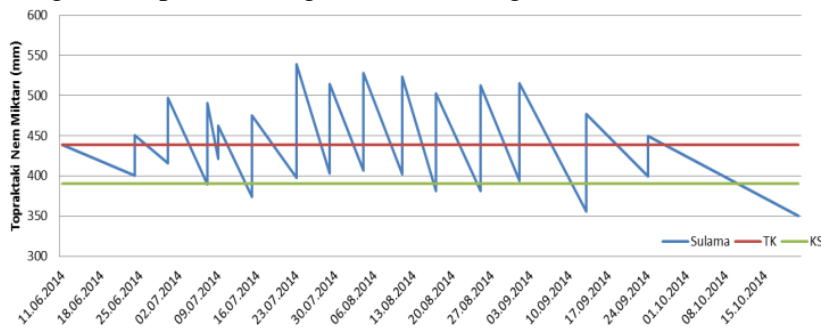

Figure 3 Irrigation practice of the farmers (Kumkale-Tomato)

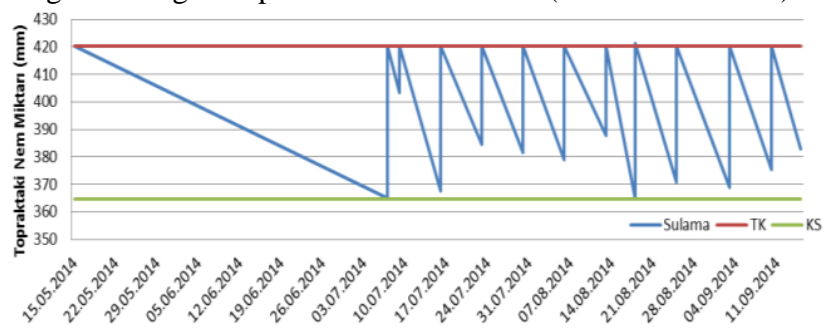

Figure 4 Optimum irrigation scheduling (Kumkale-Maize)

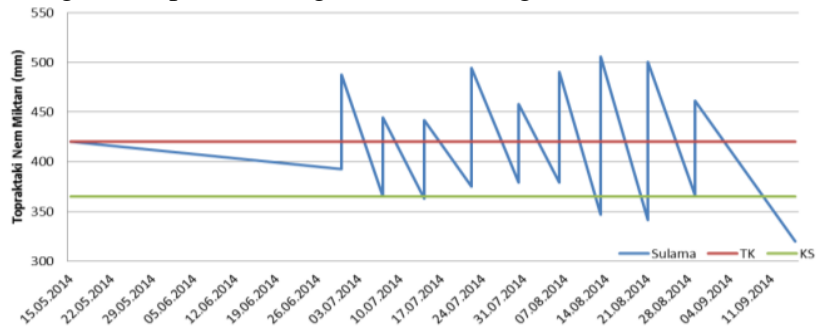

Figure 5 Irrigation practice of the farmers (Kumkale-Maize)

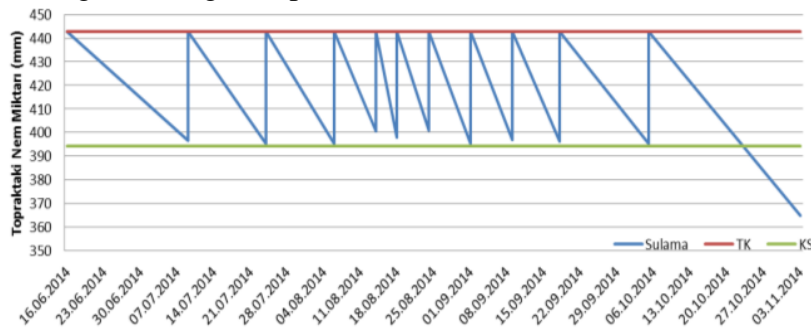

Figure 6 Optimum irrigation scheduling (Mahmudiye-Tomato)

Table 4 Water use efficiency indicators (Kumkale-Tomato)

\begin{tabular}{|c|c|c|}
\hline \multirow{2}{*}{ Indicators } & \multicolumn{2}{|c|}{ Irrigation Schedule } \\
\hline & Optimum & Farmer \\
\hline Number of Irrigations & 10 & 14 \\
\hline Amount of Irrigation ( $\mathrm{mm} /$ year) & 531 & 1.414 \\
\hline Economic Yield (kg/da) & 5.666 .5 & 3.500 \\
\hline IWUE $(\mathrm{kg} / \mathrm{da} / \mathrm{mm})$ & 10.7 & 2.5 \\
\hline RIS & 1.12 & 2.98 \\
\hline
\end{tabular}

Table 5 Water use efficiency indicators (Kumkale-Maize)

\begin{tabular}{|c|c|c|}
\hline \multirow{2}{*}{ Indicators } & \multicolumn{2}{|c|}{ Irrigation Schedule } \\
\hline & Optimum & Farmer \\
\hline Number of Irrigations & 8 & 9 \\
\hline Amount of Irrigation ( $\mathrm{mm} /$ year) & 512 & 975 \\
\hline Economic Yield $(\mathrm{kg} / \mathrm{da})$ & 898.3 & 687.5 \\
\hline IWUE $(\mathrm{kg} / \mathrm{da} / \mathrm{mm})$ & 1.8 & 0.7 \\
\hline RIS & 1.26 & 2.40 \\
\hline
\end{tabular}

The yield obtained from current practices of farmers was quite lower than the optimum values obtained under Çanakkale conditions (Table 4).

Such a case is also remarkable in irrigation water use efficiency (IWUE) and relative irrigation supply (RIS) values. As compared to optimum, $883 \mathrm{~mm}$ more water applied in farmer irrigations, corresponding to $166.3 \%$ (RIS) more water and $76.8 \%$ (IWUE) less yield was obtained.

The optimum schedule prepared for maize irrigation in piped network of Kumkale revealed that soil moisture levels were not below the critical level and amount of applied irrigation water was all the time below field capacity (Figure 4).

However, in farmer practices (Figure 5), similar to tomato irrigation, soil moisture level dropped below the critical level twice and excess water was applied in all irrigations for maize.

As it was again in tomato culture, maize yield of farmers was also quite lower than the optimum yields for Çanakkale province (Table 5). Such a case was also clearly remarkable in irrigation water use efficiency (IWUE) and relative irrigation supply (RIS) values. As compared to optimum, $463 \mathrm{~mm}$ more water applied in farmer irrigations, corresponding to $90.4 \%$ (RIS) more water and 59.8\% (IWUE) less yield was obtained.

Since water was available at desired amount and time for tomato in open-canal network of Mahmudiye village, optimum schedule was prepared as not to drop the soil moisture below the critical level and not to exceed field capacity in each time (Figure 6).

On the other hand, in farmer irrigations for tomato, soil moisture dropped below the critical level twice and excess water (more than field capacity) was applied in 5 irrigations (Figure 7).

Not being as bad as tomato farmers of Kumkale, tomato yields of farmers in Mahmudiye were also lower than the optimum yields under Çanakkale conditions (Table 6). Only $35 \mathrm{~mm}$ more water was applied to tomato plots as compared to the optimum value and such a value corresponded to $7.7 \%$ (RIS) more water than the need and $34.5 \%$ (IWUE) less yield was obtained. Such a case was probably resulted from drops in soil moisture below the critical level twice especially in periods when the plants were sensitive to moisture deficits and also from decreased fertilizer efficiencies due to excess water applications in 5 of 15 irrigations.

As it was in tomato culture, optimum schedule for maize of Mahmudiye was also so prepared as not to drop the soil moisture below the critical level and not to exceed field capacity in each time (Figure 8).

However there were serious mistakes made in farmer maize irrigations. Farmers practiced only one irrigation and it dropped soil moisture level way below the critical level and the amount applied in this irrigation was quite more than the field capacity (Figure 9).

As can be inferred from Table 7, maize yields of Mahmudiye farmers with their irrigation practices were quite lower than the optimum yields to be obtained under Çanakkale conditions. As compared to optimums, 151 $\mathrm{mm}$ more water was applied to maize plots and such a value corresponded to $39.8 \%$ (RIS) more water than the need and ultimately $59.1 \%$ (IWUE) less yield was obtained. 
Table 6 Water use efficiency indicators (Mahmudiye-Tomato)

\begin{tabular}{l|cc}
\hline \multirow{2}{*}{\multicolumn{1}{c|}{ Indicators }} & \multicolumn{2}{|c}{ Irrigation Schedule } \\
\cline { 2 - 3 } & Optimum & Farmer \\
\hline Number of Irrigations & 14 & 15 \\
Amount of Irrigation (mm/year) & 457 & 492 \\
Economic Yield (kg/da) & 8.612 .5 & 6.071 .4 \\
IWUE (kg/da/mm) & 18.8 & 12.3 \\
RIS & 1.31 & 1.41 \\
\hline
\end{tabular}

Table 7 Water use efficiency indicators (Mahmudiye-Maize)

\begin{tabular}{l|cc}
\hline \multirow{2}{*}{\multicolumn{1}{c|}{ Indicators }} & \multicolumn{2}{|c}{ Irrigation Schedule } \\
\cline { 2 - 3 } & Optimum & Farmer \\
\hline Number of Irrigations & 12 & 1 \\
Amount of Irrigation (mm/year) & 379 & 228 \\
Economic Yield (kg/da) & 8.052 .5 & 1.980 \\
IWUE (kg/da/mm) & 21.2 & 8.7 \\
RIS & 1.41 & 0.85 \\
\hline
\end{tabular}

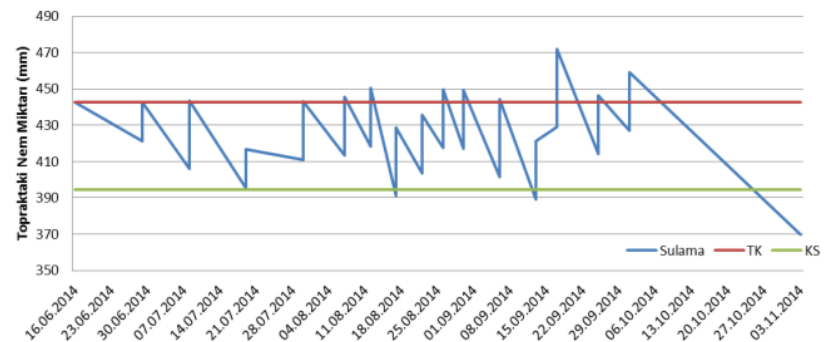

Figure 7 Irrigation practice of the farmers (Mahmudiye-Tomato)

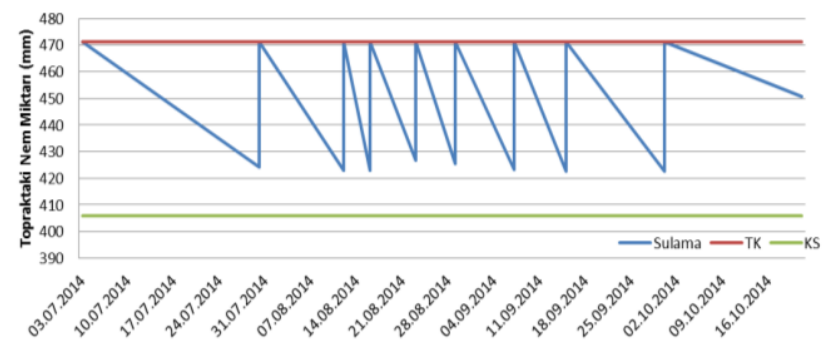

Figure 8 Optimum irrigation scheduling (Mahmudiye-Maize)

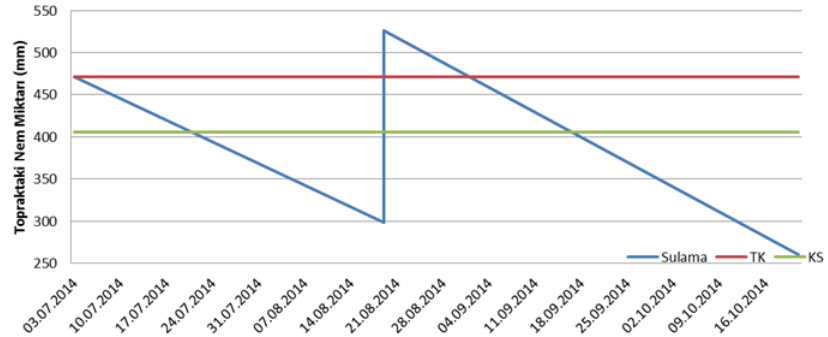

Figure 9 Irrigation practice of the farmers (Mahmudiye-Maize)

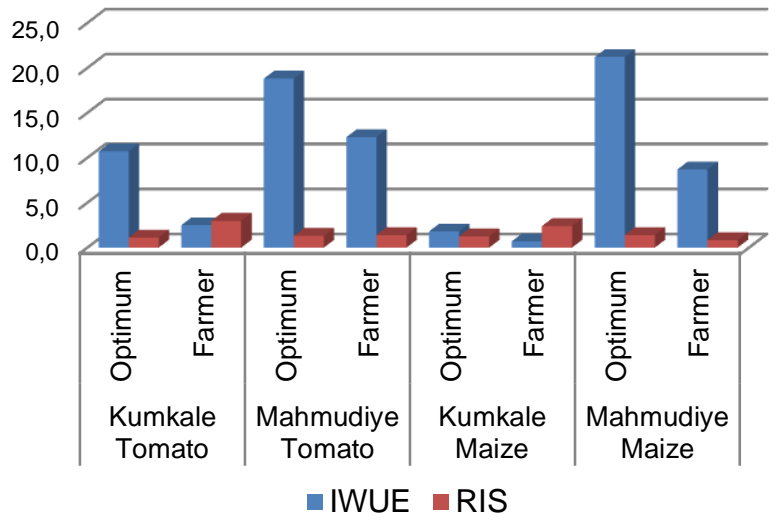

Figure 10 Results for water use efficiencies

\section{Conclusion and Recommendations}

In present study, irrigation practices of four farmers dealing with agricultural activities over Çanakkale Kumkale plain were assessed. Two farmers were selected from Kumkale village with piped-network and two farmers from Mahmudiye village with open-canal irrigation network. Farmers were growing tomato and maize in selected experimental plots. Plant water consumptions were calculated by using the data from Class-A evaporation pan and an optimum irrigation schedule was prepared for each plot. Farmer yield data were used to calculate irrigation water use efficiency (IWUE) and relative irrigation supply (RIS) values. Farmer practices were then compared with optimum conditions.

Entire findings are presented in Figure 10. It was clearly observed that farmer practices were quite different from the optimum conditions. There were several mistakes made in irrigation practices of the farmers. The farmer growing tomato in Mahmudiye village with opencanal irrigation network made relatively less mistakes than the other farmers. On the other hand, the farmer growing tomato in Kumkale village with piped-network made more mistakes in irrigation practices than the other farmers and had the least yield as compared to optimum conditions.

It was concluded that type of irrigation network (either open-canal or piped network) did not have significant effects on irrigation schedules of the farmers.

Considering the deficit water resources of the country, it was finally concluded that farmers should practice optimum irrigation schedules for an efficient water use in irrigations. Regulations should be made urgently to direct farmers to pressurized closed-piped irrigation methods with high water application efficiencies and to also direct them to optimum schedules.

\section{References}

Anonymous. 2006. Water A Shared Responsibility. The United Nations World Water Development Report 2. ISBN UNESCO 92-3-104006-5.

Doorenbos J, Pruitt WO. 1992. Crop Water Requirements. Irrigation and Drainage Paper No: 33, FAO, Roma, p. 8.

Eylen M, Kanber R, Tok A. 1986. Çukurova Koşullarında Karık ve Damla Sulama Yöntemleri İle Sulanan Çileğin Verim ve Su Tüketimi. Köy Hizmetleri Araştırma Enstitüsü Yayınları 135. 77. 39 s. Tarsus.

GTHB. 2016. Çanakkale İ Gıda Tarım ve Hayvancılık Müdürlüğ̈̈ $2014 \quad$ Y1lı Brifing Raporu. http://canakkale.tarim.gov.tr/Menu/13/Brifingler. Erişim Tarihi: 15.12.2016.

Howell TA, Cuenca HA, Solomon KH. 1990. Crop Yield response. Management of Farm Irrigation Systems. Trans. ASAE Monograph Chap S. USA.

Kanber R, Köksal H, Önder S, Eylen M. 1994. Farklı Sulama Yöntemlerinin Genç Portakal Ağaçlarında Veri, Su Tüketimi ve Kök Gelişimine Etkileri. J. of. Agriculture and Forestry 20 (1996) 163-172.

Karagöz Ö. 2001. Çanakkale İlinin İklim Özellikleri ve Tarıma Olan Etkileri. Çanakkale Onsekiz Mart Üniversitesi Lisans Bitirme Tezi. Çanakkale. 
Rijetama PE. 1970. Soil Moisture Forecasting, Inastituut voor Culturtechniek en Waterhuishouding Wageningen, Page 28.

TAGEM 2016. Gıda Tarım ve Hayvancılık Bakanlığı. Türkiye'de Sulanan Bitkilerin $\mathrm{Su}$ Tüketim Rehberi. http://www.tarim.gov.tr/TAGEM/Belgeler/T\%C3\%BCrkiye de\%20Sulanan\%20Bitkilerin\%20Su\%20T\%C3\%BCketimi \%20Rehberi\%205-9-2016.pdf. Erişim Tarihi: 15.12.2016.
TÜİK 2014. Bitkisel Üretim İstatistikleri, Türkiye İstatistik Kurumu 30.04.2015, http://www.tuik.gov.tr/UstMenu.do? metod=temelist.

Yıldırım O, Korukçu A. 1999. Damla Sulama Sistemlerinin Projelendirilmesi. Ankara Üniversitesi Ziraat Fakültesi, Ankara 